\title{
Front Matter: Volume 7592
}

, "Front Matter: Volume 7592," Proc. SPIE 7592, Reliability, Packaging, Testing, and Characterization of MEMS/MOEMS and Nanodevices IX, 759201 (24 March 2010); doi: 10.1117/12.861997

SPIE. Event: SPIE MOEMS-MEMS, 2010, San Francisco, California, United States 


\section{PROCEEDINGS OF SPIE}

\section{Reliability, Packaging, Testing, and Characterization of MEMS/MOEMS and Nanodevices IX}

Richard C. Kullberg

Rajeshuni Ramesham

Editors

25-26 January 2010

San Francisco, California, United States

Sponsored and Published by

SPIE

Volume 7592 
The papers included in this volume were part of the technical conference cited on the cover and title page. Papers were selected and subject to review by the editors and conference program committee. Some conference presentations may not be available for publication. The papers published in these proceedings reflect the work and thoughts of the authors and are published herein as submitted. The publisher is not responsible for the validity of the information or for any outcomes resulting from reliance thereon.

Please use the following format to cite material from this book:

Author(s), "Title of Paper," in Reliability, Packaging, Testing, and Characterization of MEMS/MOEMS and Nanodevices IX, edited by Richard C. Kullberg, Rajeshuni Ramesham, Proceedings of SPIE Vol. 7592 (SPIE, Bellingham, WA, 2010) Article CID Number.

ISSN 0277-786X

ISBN 9780819479884

Published by

SPIE

P.O. Box 10, Bellingham, Washington 98227-0010 USA

Telephone +1 3606763290 (Pacific Time) · Fax +1 3606471445

SPIE.org

Copyright (c) 2010, Society of Photo-Optical Instrumentation Engineers

Copying of material in this book for internal or personal use, or for the internal or personal use of specific clients, beyond the fair use provisions granted by the U.S. Copyright Law is authorized by SPIE subject to payment of copying fees. The Transactional Reporting Service base fee for this volume is $\$ 18.00$ per article (or portion thereof), which should be paid directly to the Copyright Clearance Center (CCC), 222 Rosewood Drive, Danvers, MA 01923. Payment may also be made electronically through CCC Online at copyright.com. Other copying for republication, resale, advertising or promotion, or any form of systematic or multiple reproduction of any material in this book is prohibited except with permission in writing from the publisher. The CCC fee code is 0277-786X/10/\$18.00.

Printed in the United States of America.

Publication of record for individual papers is online in the SPIE Digital Library.

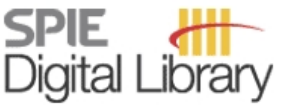

SPIEDigitalLibrary.org

Paper Numbering: Proceedings of SPIE follow an e-First publication model, with papers published first online and then in print and on CD-ROM. Papers are published as they are submitted and meet publication criteria. A unique, consistent, permanent citation identifier (CID) number is assigned to each article at the time of the first publication. Utilization of CIDs allows articles to be fully citable as soon they are published online, and connects the same identifier to all online, print, and electronic versions of the publication. SPIE uses a six-digit CID article numbering system in which:

- The first four digits correspond to the SPIE volume number.

- The last two digits indicate publication order within the volume using a Base 36 numbering system employing both numerals and letters. These two-number sets start with 00, 01, 02, 03, 04 , 05, 06, 07, 08, 09, OA, OB ... 0Z, followed by 10-1Z, 20-2Z, etc.

The CID number appears on each page of the manuscript. The complete citation is used on the first page, and an abbreviated version on subsequent pages. Numbers in the index correspond to the last two digits of the six-digit CID number. 


\title{
Contents
}

\author{
vii Conference Committee \\ ix Introduction \\ xi Emerging research in micro and nano systems: opportunities and challenges for societal \\ impact (Plenary Paper) [7593-201] \\ Y. B. Gianchandani, Univ. of Michigan (United States) \\ xix MEMS technologies for artificial retinas (Plenary Paper) [7594-202] \\ W. Mokwa, RWTH Aachen Univ. (Germany) \\ xxxiii Shaping light: MOEMS deformable mirrors for microscopes and telescopes (Plenary Paper) \\ [7595-203] \\ T. Bifano, Boston Univ. Photonics Ctr. (United States)
}

\section{SESSION 1 MEMS PACKAGING: HERMETICITY CHARACTERIZATION}

759202 Nanoengineered surfaces for microfluidic-based thermal management devices (Invited Paper) [7592-01]

E. N. Wang, R. Xiao, K.-H. Chu, Massachusetts Institute of Technology (United States)

759203 A new method for hermeticity testing of wafer-level packaging [7592-02]

D. Lellouchi, J. Dhennin, NOVA MEMS (France); X. Lafontan, INTESENS (France); D. Veyrie, CNES (France); A. Broue, NOVA MEMS (France) and LAAS, CNRS, Univ. of Toulouse (France); J.-F. Le Neal, LAAS, CNRS, Univ. of Toulouse (France) and Esterline Advanced Sensors (France); F. Pressecq, CNES (France)

759204 Pressure sensing in vacuum hermetic micropackaging for MOEMS-MEMS [7592-03] M. M. Sisto, S. García-Blanco, L. Le Noc, B. Tremblay, Y. Desroches, J.-S. Caron, F. Provencal, F. Picard, Institut National d'Optique (Canada)

759205 Wafer-level vacuum/hermetic packaging technologies for MEMS [7592-04] S.-H. Lee, J. Mitchell, Univ. of Michigan (United States) and ePack, Inc. (United States); W. Welch, Intek, Inc. (United States); S. Lee, Univ. of Michigan (United States) and ePack, Inc. (United States); K. Najafi, Univ. of Michigan (United States)

759206 Characterization of polymeric getter materials for MEMS/MOEMS and other microelectronic package service [7592-05]

R. C. Kulliberg, B. L. Phillip, Vacuum Energy, Inc. (United States)

759207 Hermetic vacuum sealing of MEMS devices containing organic components [7592-06] G. B. Tepolt, M. J. Mescher, J. J. LeBlanc, The Charles Stark Draper Lab., Inc. (United States); R. Lutwak, Symmetricom, Inc. (United States); M. Varghese, MEMSIC, Inc. (United States) 
759208 Predicting reliability of silicon MEMS (Invited Paper) [7592-07]

A. M. Fitzgerald, D. M. Pierce, B. Zeyen, A.M. Fitzgerald \& Associates, LLC (United States)

759209 Stability experiments on MEMS aluminum nitride RF resonators [7592-08]

D. M. Tanner, R. H. Olsson III, T. B. Parson, S. M. Crouch, J. A. Walraven, J. A. Ohlhausen, Sandia National Labs. (United States)

7592 OA Characterization of AU/AU, AU/RU, and Ru/Ru ohmic contacts in MEMS switches improved by a novel methodology [7592-09]

A. Brove, NOVA MEMS (France) and LAAS, CNRS, Univ. de Toulouse (France); J. Dhennin, NOVA MEMS (France); F. Courtade, CNES (France); C. Dieppedale, CEA-LETI (France); P. Pons, LAAS, CNRS, Univ. de Toulouse (France); X. Lafontan, NOVA MEMS (France) and INTESENS (France); R. Plana, LAAS, CNRS, Univ. de Toulouse (France)

7592 OB Novel test fixture for collecting microswitch reliability data [7592-10] T. A. Edelmann, R. A. Coutu, Jr., L. A. Starman, Air Force Institute of Technology (United States)

7592 OC Reliability study of a MEMS array under varying temperature and humidity conditions [7592-11]

G. Sivakumar, R. Ranganathan, R. Gale, T. Dallas, Texas Tech Univ. (United States)

\section{SESSION 3 PACKAGING AND MEMS RELIABILITY}

7592 OD The effects of plasma pretreatment and storage time on silicon fusion bonding (Invited Paper) [7592-12]

C. B. O'Neal, J. Soman, Lovisiana Tech Univ. (United States)

7592 OE Lifetime estimation and reliability study of electrothermal MEMS actuators [7592-13] G. Sivakumar, Texas Tech Univ. (United States); S. Johns, Baylor Univ. (United States); J. A. Nava, Angelo State Univ. (United States); T. Dallas, Texas Tech Univ. (United States)

7592 OF Reliability assessment of ceramic column grid array (CCGA717) interconnect packages under extreme temperatures for space applications $\left(-185^{\circ} \mathrm{C}\right.$ to $\left.+125^{\circ} \mathrm{C}\right)[7592-14]$ R. Ramesham, Jet Propulsion Lab. (United States)

7592 OG Packaged bulk micromachined triglyceride biosensor [7592-15] S. V. Mohanasundaram, S. Mercy, P. V. Harikrishna, K. Rani, E. Bhattacharya, A. Chadha, Indian Institute of Technology Madras (India)

$7592 \mathrm{OH} \quad$ MEMS/microfluidics packaging without heating (Invited Paper) [7592-16] M. R. Howlader, McMaster Univ. (Canada)

7592 ol Use of conductive adhesive for MEMS interconnection in military fuze applications [7592-17]

J. Gakkestad, P. Dalsjo, Norwegian Defence Research Establishment (Norway);

H. Kristiansen, Conpart AS (Norway); R. Johannessen, M. M. V. Taklo, SINTEF ICT (Norway) 
$7592 \mathrm{JJ} \quad$ Modeling time-dependent dielectric breakdown with and without barriers (Invited Paper) [7592-18]

J. L. Plawsky, W. N. Gill, R. S. Achanta, Rensselaer Polytechnic Institute (United States)

7592 OK Remotely accessible laboratory for MEMS testing [7592-19]

G. Sivakumar, M. Mulsow, A. Melinger, S. Lacouture, T. E. Dallas, Texas Tech Univ. (United States)

$7592 \mathrm{OL}$ Optical inspection of MOEMS devices using a configurable and suitable for production image processing system [7592-20]

M. Scholles, M. Grafe, P. Miskowiec, V. Bock, H. Schenk, Fraunhofer Institute for Photonic Microsystems (Germany)

7592 OM Low-cost system for testing MEMS for research and educational applications [7592-21]

G. Ramirez, G. Sivakumar, S. Lacouture, T. Dallas, Texas Tech Univ. (United States)

\section{SESSION $5 \quad$ MEMS APPLICATIONS}

7592 ON Engineered nanowires, carbon nanotubes and graphene for sensors, actuators and electronics (Invited Paper) [7592-22]

E. H. Yang, Stevens Institute of Technology (United States)

759200 Optimal design of SAW-based gyroscope to improve sensitivity [7592-23]

H. Oh, S. Yang, K. Lee, Ajou Univ. (Korea, Republic of)

7592 OP Temperature measurement on MOEMS micromirror plates under illumination [7592-24]

I. Wullinger, D. Rudloff, K. Lukat, P. Dürr, M. Krellmann, D. Kunze, A. Narayana Samy,

U. Dauderstädt, M. Wagner, Fraunhofer Institute for Photonic Microsystems (Germany)

$75920 Q \quad$ Development and testing of a multi-level chevron actuator based positioning system [7592-25]

S. Rawool, G. Sivakumar, J. Hendriske, D. Buscarello, Texas Tech Univ. (United States);

I. Purushothaman, Arizona State Univ. (United States); T. E. Dallas, Texas Tech Univ. (United States)

7592 OR Development of a microlens array (MLA) for maskless photolithography application [7592-26]

M. Nam, H. Oh, G. Kim, S. Yang, K. Lee, Ajou Univ. (Korea, Republic of)

7592 OS A 2-DOF MEMS positioning system [7592-27]

G. Sivakumar, Texas Tech Univ. (United States); J. Mathews, Angelo State Univ. (United States); T. E. Dallas, Texas Tech Univ. (United States)

7592 OT The influence of the arrangement and spacing of CNT column array on the characteristic of field emission [7592-28]

K. Han, D. Jun, N. T. Hong, S. Lee, S. Yang, Ajou Univ. (Korea, Republic of) 
7592 OU Self-aligned maskless process for etching cavities in SOI wafers to enhance the quality factor of MEMS resonators [7592-29]

W. Mohammad, V. Kaajakari, Lovisiana Tech Univ. (United States)

\section{SESSION 6 MECHANICAL PROPERTIES}

$75920 \mathrm{~V}$ Thermal microactuator performance as a function of mechanical stress [7592-30]

L. M. Phinney, M. A. Spletzer, M. S. Baker, J. R. Serrano, Sandia National Labs. (United States)

7592 OW Mitigating the irreversible deformation with pressure in silicon/porous silicon composite membranes [7592-31]

L. Sujatha, Rajalakshmi Engineering College (India); R. Goswami, E. Bhattacharya, Indian Institute of Technology Madras (India)

7592 0X Investigation into metamaterial structures operating at terahertz wavelength [7592-32]

D. Langley, R. A. Coutu, Jr., L. A. Starman, M. A. Marciniak, Air Force Institute of Technology (United States)

\section{POSTER SESSION}

$75920 Z$ Performance and reliability assessment of a dielectric charging guard in MEMS optical switch systems [7592-36]

P. Zhang, E. Carr, D. Keebaugh, K. Chau, Glimmerglass Networks, Inc. (United States)

Author Index 


\title{
Conference Committee
}

\author{
Symposium Chair
}

Thomas J. Suleski, The University of North Carolina at Charlotte (United States)

Symposium Cochair

Harald Schenk, Fraunhofer Institute for Photonic Microsystems (Germany)

Conference Chairs

Richard C. Kullberg, Vacuum Energy Inc. (United States)

Rajeshuni Ramesham, Jet Propulsion Laboratory (United States)

Program Committee

Enakshi Bhattacharya, Indian Institute of Technology Madras (India)

Jason O. Clevenger, Exponent, Inc. (United States)

Sonia García-Blanco, Institut National d'Optique (Canada)

Christopher K. Harrison, Schlumberger-Doll Research Center (United States)

Allyson L. Hartzell, Boston Micromachines Corporation (United States)

Albert K. Henning, Nanolnk, Inc. (United States)

Maurice S. Karpman, Charles Stark Draper Laboratory, Inc. (United States)

Keekeun Lee, Ajou University (Korea, Republic of)

Olivier N. Pierron, Georgia Institute of Technology (United States)

Jeff Pulskamp, Army Research Laboratory (United States)

Herbert R. Shea, Ecole Polytechnique Fédérale de Lausanne

(Switzerland)

Danelle M. Tanner, Sandia National Laboratories (United States)

Yanzhu Zhao, Medtronic, Inc. (United States)

\section{Session Chairs}

1 MEMS Packaging: Hermeticity Characterization

Rajeshuni Ramesham, Jet Propulsion Laboratory (United States)

2 Reliability and RF MEMS

Leslie M. Phinney, Sandia National Laboratories (United States) 
3 Packaging and MEMS Reliability

Sonia García-Blanco, Institut National d'Optique (Canada)

$4 \quad$ MEMS Testing and Inspection

Richard C. Kullberg, Vacuum Energy, Inc. (United States)

5 MEMS Applications

Danelle M. Tanner, Sandia National Laboratories (United States)

Allyson L. Hartzell, Boston Micromachines Corporation (United States)

6 Mechanical Properties

Alissa M. Fitzgerald, A.M. Fitzgerald \& Associates, LLC (United States) 


\section{Introduction}

The reliability, packaging, testing, and characterization of MEMS/MOEMS are of paramount importance to the commercialization of these advanced and useful emerging technologies. Contributors to this conference attend from around the world, making it the premier international reliability conference for MEMS/MOEMS. The main objective of this conference is to provide a technical forum for in-depth investigations and interdisciplinary discussions involving reliability, packaging, testing, and characterization of MEMS/MOEMS. The response to the call for papers has been incredible over the years and technically rewarding to the MEMS/MOEMS and associated communities.

The Reliability, Packaging, Testing, and Characterization of MEMS/MOEMS and Nanodevices conference is sponsored by SPIE, and was organized as a part of Photonics West 2010. SPIE is the leading international forum for presentation of the latest developments associated with MEMS and MOEMS including reliability, testing, packaging, materials, surfaces, and characterization. Our conference was part of the Devices/Applications/Reliability symposium track and education program on MOEMS-MEMS held 24-29January 2010 at Moscone Center, San Francisco, California, USA. This conference has been held for over 10 consecutive years in various forms through the SPIE.

In preparing for the conference, 36 high-quality papers were received from various countries. This year six sessions covered MEMS Packaging: Hermeticity Characterization, Reliability and RF MEMS, Packaging and MEMS Reliability, MEMS Testing and Inspection, MEMS Applications, and Mechanical Properties of materials of MEMS. Our final technical program had three plenary speakers and six invited/keynote speakers from various reputed laboratories around the country and the globe.

We would like to personally thank Dr. Leslie Phinney, Dr. Danelle Tanner, Dr. Sonia García-Blanco, Dr. Allyson Hartzell, Ms. Alyssa M. Fitzgerald, and Dr. Thomas Suleski and Dr. Herald Schenk (symposium chair and cochair), as well as the SPIE staff for their unstinted timely support and encouragement. Finally, we would like to thank all the session chairs and cochairs, and the program committee members for their support in organizing this conference successfully and reviewing the abstract and proceedings articles. We thank all the participants and everyone who participated in this conference.

Richard C. Kullberg Rajeshuni Ramesham 
Downloaded From: https://www.spiedigitallibrary.org/conference-proceedings-of-spie on 26 Apr 2023

Terms of Use: https://www.spiedigitallibrary.org/terms-of-use 